Д-р Шири Шинан-Алтман, доктор на науки, Школа за социјална работа Луис и Габи Вајсфелд, Универзитет Бар Илан, Рамат-Ган, Израел. Автор за кореспонденција: shiri.altman@biu.ac.il

Д-р Инбар Левкович, доктор на науки, Факултет за постдипломски студии, Академски колеџ за образование Ораним, Израел.

Д-р Амит Порат, магистер на науки, Оддел за семејна медицина, Медицински факултет Рут и Брус Рапапорт, Технион - Израелски институт за технологија, Здравствени услуги Клалит, област Хаифа и Западна Галилеја, Израел.

Д-р Мордехај Алперин, магистер на науки, Оддел за семејна медицина, Медицински факултет Рут и Брус Рапапорт, Технион - Израелски институт за технологија, Здравствени услуги Клалит, област Хаифа и Западна Галилеја, Израел.

\title{
ВЛИЈАНИЕТО НА ЕПИДЕМИЈАТА СО КОВИД-19 ВРЗ ИСКУСТВАТА НА ПОВОЗРАСНИТЕ ЛИЦА ВО ОДНОС НА ЗДРАВСТВЕНИТЕ УСЛУГИ
}

\section{Апстракт}

Цел: Одржувањето на побарувачката на неопходните здравствени услуги за време на една пандемиска криза е несомнено важно, а особено кога станува збор за повозрасните лица. За таа цел, оваа студија имаше за цел да ги испита факторите поврзани со искуствата во однос на здравствените услуги што им се нудат на повозрасните лица во Израел за време на пандемијата со КОВИД-19.

Методи: Спроведена е репрезентативна анкета преку Интернет на 261 повозрасни лица (на возраст над 60 години). Учесниците комплетираа прашања за согледаниот здравствен статус, согледаниот ризик од КОВИД-19, сознанијата за КОВИД-19, нивото на депресија, ресурсите за справување, и искуството во однос на здравствените услуги (контакт со матичен лекар, страв од заразување со вирусот преку директен контакт со здравствениот систем). Беа пресметани две повеќекратни регресии за следните зависни променливи: контакт со матичен лекар за време на КОВИД-19 и страв од заразување со вирусот преку директен контакт со здравствениот систем за време на КОВИД-19.

Резултати: Контактот на повозрасните лица со матичниот лекар за време на КОВИД-19 се намалил во однос на нивниот контакт пред пандемијата. Зголемениот број на контакти со матичниот лекар за време на КОВИД-19 
се должел на поголемите сознанија за КОВИД-19. Освен тоа, повисокиот степен на страв од заразување со вирусот преку директен контакт со здравствениот систем за време на КОВИД-19 се поврзува со понизок степан на образование, повисок ризик за КОВИД-19 и помали сознанија за КОВИД-19.

Заклучоци: Резултатите можат да им дадат на креаторите на јавните здравствени политики поцелосна слика за влијанието на кризата КОВИД-19 кај повозрасните лица. Оваа студија ги посочува карактеристиките и факторите коишто ги охрабруваат/ обесхрабруваат повозрасните лица да бараат здравствени услуги за време на епидемија со вирус, како што е пандемијата со КОВИД-19.

Клучни зборови: ресурси за справување, КОВИД-19, депресија, искуства со здравствените услуги, сознанија за КОВИД-19, повозрасни лица, согледан ризик.

\section{Вовед}

Повеќето студии коишто спроведени ширум целиот свет укажуваат на тоа дека корона вирусот (КОВИД-19) значително се поврзува со намалено користење на здравствената заштита (Lazzerini et al., 2020; Shinan-Altman et al., 2020). На пример, во Соединетите Држави процентот на пациенти со тежок срцев удар коишто биле третирани во девет поголеми медицински центри се намалил за 38\% (Garcia et al., 2020); во Италија, забележано е намалување на процентот на посети во одделот за итни случаи кај деца од 73\% до 88\% (Lazzerini et al., 2020); додека во Израел, 88\% од пациентите со рак на дојка го откажале својот термин во здравствените установи поради КОВИД-19 (Shinan-Altman et al., 2020). Друга студија спроведена во Израел покажала дека во рок од два месеци по појавата на КОВИД-19, просечниот број на посети во одделот за итни случаи опаднал за 30,2\% а исполнетоста на капацитетот на болницата за 29,2\%, во споредба со истиот период претходната година (Basis et al., 2020). Намаленото или одложено користење на здравствената заштита за време на пандемија може да има штетни последици по здравјето (Shinan-Altman et al., 2020). Ова е особено точно за повозрасните лица (на возраст над 60 години), бидејќи намаленото користење на здравствените услуги може да има и физичко и емоционално влијание врз нив (Morrow-Howell et al., 2020). Поточно, кризата со КОВИД-19 поттикна страв и депресија кај постарите луѓе, особено како резултат на извештаите и доказите коишто покажуваат дека оваа популација има повисоки стапки на смртност и поголема подложност на заразување со вирусот (Radwan et al., 2020). За време на епидемии и други здравствени кризи, повозрасните лица се соочуваат со тешки предизвици (Morrow-Howell et al., 2020). Бидејќи повозрасните лица честопати се обраќаат на својот матичен лекар за да се справат со здравствените и менталните 
проблеми (Elliott et al., 2018), улогата на матичните лекари станува уште позначајна за време на таквите периоди.

Континуитетот на грижата и лекувањето е еден од централните принципи на семејната медицина (Adar et al., 2017; Jahromi et al., 2017), а ова е особено важно во време на пандемија. Во рамките на примарната здравствена заштита, континуитетот на грижата најчесто се гледа преку односот лекар-пациент којшто се протега и вон случаите на болест (Elliott et al., 2018). Сепак, за време на епидемијата со КОВИД-19, се чини дека еден од главните ризици за повозрасните лица е неможноста да добијат рутинска медицинска нега во заедницата. Ваквата ситуација може да се објасни на неколку начини: Прво, на повозрасните лица им беше препорачано да ги почитуваат мерките за изолација и да го ограничат своето движење со цел да се заштитат од заразување (израелско Министерство за здравство; М3, 2020). Второ, здравствениот систем го ограничи својот фокус на управување со пациенти со КОВИД-19, што значи дека другите термини и процедури беа одложувани или откажувани (Morrow-Howell et al., 2020). Трето, ограничувањата за патување им ја отежнаа можноста на некои повозрасни лица да дојдат до соодветните здравствените установи. Конечно, стравот од заразување со вирусот при посета на здравствените установи доведе до зголемено одложување и откажување на термините (Светска здравствена организација, 2020).
Како последица на тоа, повозрасните лица не беа во можност да ги добијат потребните здравствени услуги во овој период (Morrow-Howell et al., 2020). Co цел да се објасни оваа појава, сегашната студија имаше за цел да ги испита факторите поврзани со искуствата на повозрасните лица во Израел во однос на здравствените услуги за време на пандемијата со КОВИД-19.

Претходните студии во областа на побарувачката на здравствени услуги покажаа различни когнитивни и емоционални променливи, како и ресурси за справување со кои може да се објасни користењето на здравствените услуги. Коїнииивнийе ирроменливи вклучуваат перцепции (на пр., согледан здравствен статус, согледан ризик од заразување со болест/ вирус) и сознанија на некоја болест/вирус (Rastogi, Madhok and Kipperman, 2013; Shinan-Altman et al., 2020). Во однос на емоционалнииее ироменливи, оваа студија се концентрираше на депресијата, во Израел слично како и во другите земји (на пр. Castro-Costa et al., 2007; Li et al., 2014) - едно на секои четири повозрасни лица има значителни симптоми на депресија (Bentur and Heymann, 2020). Освен тоа, позначајни симптоми на депресија се забележани кај повозрасни лица за време на епидемијата со КОВИД-19 (Santini et al., 2020). Понатаму, се покажа дека позначајните симптоми на депресија се поврзани со зголемена искористеност на амбулантските ресурси и повеќе посети на матичните лекари (Bentur and Heymann, 2020). На крај, 
оваа студија ги опфаќа ресурсийе за сиравување коишто подразбираат оптимизам (внатрешен ресурс) и социјална поддршка (надворешен ресурс), бидејќи се покажа дека овие ресурси за справување се значително поврзани со побарувачката на здравствени услуги (DeViva et al., 2020; ng Wang et al., 2020)

И когнитивните и емоционалните фактори, заедно со ресурсите за справување, имаат значајно влијание врз начинот на кој поединците успеваат да се справат со заканите по здравјето (Zhang et al., 2014). Сепак, студиите во однос на овие концепти за време на КОВИД-19 почнаа да се појавуваат од неодамна, и според најдобрите сознанија, ниедна студија сѐ уште не ги испитала целосно овие фактори кај повозрасни лица за време на пандемија. За таа цел, целта на оваа студија е да се испитаат детерминантите на искуствата на повозрасните лица во однос на здравствените услуги за време на КОВИД-19. Подлабокиот увид во механизмите поврзани со користењето на здравствените услуги кај повозрасни лица може да помогне во подобрување на нивните индикатори за физичкото и менталното здравје, особено за време на епидемија со вирус.

\section{Метод}

Постапка: Студијата беше спроведена со „Здравствени услуги на Клалит“ (областа Хаифа и Западна Галилеја), најголемата непрофитна организација за здравствена нега (ОЗН) во Израел. Податоците беа собрани во периодот од јуни и јули 2020 година. Овој временски период го одразуваше намалувањето на првиот бран на КОВИД-19 во Израел. За тоа време, повеќе лица доставија барања за отсуство или работеа од дома. Во Израел беше воспоставена нова рутина, вклучително и задолжително носење маски за лице и строги мерки на социјално дистанцирање.

Вкупно 261 повозрасно лице учествуваше во студијата. Критериуми за вклучување: (а) осигуреник на ,Здравствени услуги Клалит“, (б) постаро лице од 60 години и (в) говорител на хебрејски јазик. Критериум за исклучување: когнитивно оштетување. Потенцијалните учесници коишто ги исполнија критериумите за вклучување беа идентификувани од менаџерите на осум клиники - половина беа од урбани, а половина во рурални области. Деталите за контакт на потенцијалните учесници беа испратени до шест практиканти по семејна медицина, кои ги контактираа и им ги објаснија карактеристиките и важноста на студијата. Пациентите кои се согласија да учествуваат беа интервјуирани од практиканти по семејна медицина преку телефон, користејќи структуриран и претходно тестиран прашалник. Од 278 пациенти од коишто се побарало согласност, 261 се согласиле да учествуваат во студијата (стапка на повратен одговор од 94\%). Вкупно 17 пациенти одбија да учествуваат поради недостаток на интерес. Студијата е одобрена од Хелсиншкиот комитет на „Здравствени услуги Клалит“ (број на одобрување 0060-20-СОМ2). 


\section{Мерки}

\section{Зависни ирроменливи}

Искуствата во однос на здравствената грижа за време на КОВИД-19 се мереа со помош на две димензии:

1. Конйакӣой со майичен лекар за време на КОВИД-19 се мереше со помош на скала од 2 ставки. Едната ставка се однесува на степенот на контакт со матичниот лекар пред епидемијата со КОВИД-19, додека другата ставка се однесува на степенот на контакт со матичниот лекар за време на епидемијата со КОВИД-19. Учесниците беа замолени да наведат колкав е нивниот контакт со матичниот лекар на Ликертовата скала од 5 бода во опсег од 1 (воопшто не) до 5 (многу често) (на пример, „Колку често бевте во контакт со матичниот лекар пред да се појави епидемијата со КОВИД-19?“"). Повисока оценка укажува на поголема зачестеност на контактите со матичниот лекар.

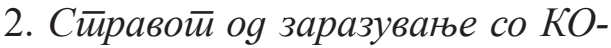

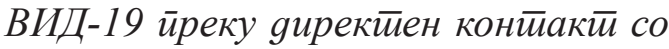
зяравстивениой сисиеме се мереше со користење на една ставка. Учесниците беа замолени да го наведат степенот на страв од заразување со КОВИД-19 што го доживеале при директна интеракција со здравствениот систем на Ликертовата скала од 5 бода во опсег од 1 (незначаен) до 5 (многу висок).

\section{Независни ироменливи}

Соїлеgаниой ризик за КОВИД-19 се оценуваше врз основа на претходни сту- дии спроведени кај лаичката јавност (на пример, Shinan-Altman and Levkovich, 2020) со помош на едно прашање: „Колкава е, според вас, веројатноста да се заразите со КОВИД-19? Одговорите беа оценети според Ликертовата скала од 5 бода, од 1 (незначајна) до 5 (многу висока).

Сознанијат̄а за КОВИД-19 се мереше со помош на тест за знаење за КОВИД-19 составен од 6 прашања. Валидноста на скалата се утврди по пат на стручно валидирање. Одговорите беа оценети според Ликертовата скала од 5 бода, во опсег од 1 (воопшто не знам ништо) до 5 (знам многу). Беше создаден композитен индекс на просекот од сите одговори, при што повисок резултат укажува на повисоки нивоа на знаење за КОВИД- $19(\alpha=0,70$ на Кронбах).

Дейресијайа се мереше со помош на прашалникот за симптоми на депресија (Центар за епидемиолошки студии за депресија, CESD- 10; Andersen et al., 1994). Овој инструмент е составен од 10 прашања и е скратена верзија од инструментот со 20 прашања (Radloff, 1977). Прашањата беа поделени во категории на позитивни (на пр., „генерално задоволни“") и негативни (на пример, „чувство на замор или слаба енергија“) (Irwin et al., 1999; Kohout et al., 1993). Учесниците беа замолени да го оценат интензитетот на нивните искуства во текот на минатата недела на Ликертовата скала од 4 бода, од 1 (никогаш) до 4 (во голема мера). По анулирањето на негативните тврдења, се пресмета 
просечната оценка, при што повисока оценка означува повисоко ниво на депресија (Кронбах $\alpha=0,75)$.

Ойиимизмоти се мереше со помош на тестот за животна ориентација (LOT-R; Scheier et al., 1994). Овој инструмент претставува скала од шест прашања, со три прашања формулирани како позитивни тврдења (на пр., „Во несигурни времиња, обично го очекувам најдоброто“) и три негативни тврдења (на пр., „Ако нешто може да тргне наопаку за мене, тоа и ќе се случи"), при што се одразуваат очекувањата на пациентот во врска со иднината. Учесниците беа замолени да наведат до кој степен се согласуваат или не се согласуваат со секое прашање на Ликертовата скала со 5 бода, во опсег од 1 (потполно се согласувам) до 5 (целосно не се согласувам). По анулирањето на негативните тврдења се пресмета просечниот резултат, при што повисоките оценки укажуваат на повисоко ниво на оптимизам $(\alpha=0,61$ на Кронбах).

Социјалнайа йоggршка се мереше со помош на Мултидимензионалната скала на согледаната социјална поддршка (Zimet et al 1988). Користејќи ја оваа скала од 12 прашања, од учесниците беше побарано да наведат до кој степен се согласуваат или не се согласуваат со секоја ставка од Ликертовата скала од 5 бода, во опсег од 1 (потполно не се согласувам) до 5 (потполно се согласувам) (на пр., „Моето семејство навистина се обидува да ми помогне“"). Пресметана е средната оценка; при што повисока оценка укажува на поголемо ниво на согледана социјална поддршка (Кронбах $\alpha=0,81$ ).

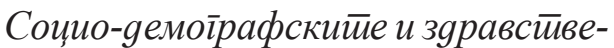

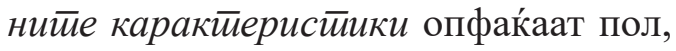
возраст, години на образование, брачен статус, број на деца со кои живеат учесниците и извори на помош за време на КОВИД-19. Во однос на здравствените карактеристики, студијата се потпираше на самостојните извештаи на учесниците во врска со: согледаниот здравствен статус ( 1 = одличен, $5=$ многу лош) и другите видови хронични болести (како хипертензија, дијабетес, коронарна срцева болест, карцином, белодробни заболувања, дијабетес, хипертензија, друго).

\section{Статистички анализи}

Податоците беа анализирани со користење на софтвер SPSS верзија 25. За да се опишат демографските карактеристики на учесниците и променливите на истражувањето се користеше описна статистика. Се пресметаа и корелациите на Пирсон за да се процени поврзаноста помеѓу студијата и суштинските променливи.

Ниту една од социо-демографските и здравствените карактеристики не е значително поврзана со контактите со матичниот лекар за време на КОВИД-19. Што се однесува до стравот од заразување со вирусот преку директен контакт со здравствениот систем за време на КОВИД-19, оваа променлива беше значително и позитивно поврзана со полот $(\mathrm{r}=0,15, \mathrm{p}<0,05)$, и значително 
и негативно поврзана со степенот на образование $(\mathrm{r}=-0,18, \mathrm{p}<0,01)$.

Пресметани се две повеќекратни регресии за зависните променливи: контакт со матичен лекар за време на КОВИД-19 и страв од заразување со вирусот преку директен контакт со здравствениот систем за време на КОВИД-19. По анализата со двете променливи, полот и степенот на образование беа вклучени во регресијата од страв од заразување со вирусот преку директен контакт со здравствениот систем за време на КОВИД-19. Сите континуирани променливи беа стандардизирани. За да ја процениме мултиколинеарноста, ги испитавме корелациите помеѓу копроменливите и не најдовме силна поврзаност (т.е. $\mathrm{r}<0,55)$.

\section{Резултати}

Опис на примерокот: Студијата опфати 261 повозрасно лице. Како што е прикажано во Табела 1, мнозинството учесници беа жени, а просечната возраст е 71,82 години, во опсег од 60 до 95 години. Мнозинството испитаници се во брак со просечно три деца. Учесниците имаа во просек 13-годишно образование, повеќето од нив живееја со интимен партнер, а околу $25,7 \%$ го доживуваат својот матичен лекар како извор на помош за време на КОВИД-19.

Во однос на здравствените карактеристики на учесниците, околу 79,5\% го сметаат својот здравствен статус за умерен до слаб; околу $83 \%$ имале хронично заболување, при што хипертензијата се

\section{Табела 1. Демографски карактеристики на учесниците $(\mathbf{n}=\mathbf{2 6 1})$}

Социо-демографски карактеристики

\section{Пол (\%) \\ Машки \\ Женски}

Средна возраст (СД), опсег

Брачна состојба (\%)

Во брак

Без партнер

Просечен број на деца (СД), опсег

Просечен број на години на образование (СД), опсег

Живее со (\%)

Сам

Интимен партнер

Член на семејството

Формален старател

Извори на помош при КОВИД-19 (\%)

Повеќе информации за КОВИД-19

Професионална поддршка (на пример, социјален работник, психолог)

Поддршка од матичен лекар

Поддршка од семејството и пријателите

Друго
$119(46,7)$

$136(53,3)$

$71,82(6,91), 60-95$

$189(74,1)$

$66(25,9)$

3,04 (1,28), 0-10

$13,10(3,11), 6-24$

$46(18,5)$

$176(70,7)$

$26(10,4)$

$1(0,4)$

$55(23,5)$

$18(7.7)$

$60(25,7)$

$56(23,9)$

$45(19,2)$

(СД = Стандардна девијација) 
појавува како водечка хронична болест [други болести се дијабетес $(8,8 \%)$, коронарна срцева болест $(10,2 \%)$, рак $(11,6 \%)$, белодробно заболување $(5,6 \%)$, дијабетес и хипертензија (19\%) и други хронични заболувања $(15,6)]$.

Описни статистики и корелации помеѓу променливите на студијата: Како што може да се види во Табела 2, просечната оценка за контактот со матичен оценка за стравот од заразување со вирусот преку директен контакт со здравствениот систем за време на епидемијата со КОВИД-19 е исто така релативно висока. Понатаму, просечната вредност за согледаниот здравствен статус, согледаниот ризик од КОВИД-19 и сознанијата за КОВИД-19 се релативно високи, додека просечната вредност за депресија е релативно ниска. Средната

Табела 2. Корелати, просеци, СД и опсези на променливите на студијата $(\mathbf{n}=\mathbf{2 6 1})$

\begin{tabular}{|c|c|c|c|c|c|c|c|c|}
\hline Променливи & 1 & 2 & 3 & 4 & 5 & 6 & 7 & 8 \\
\hline $\begin{array}{l}\text { 1. Контакт со матичен } \\
\text { лекар }\end{array}$ & - & & & & & & & \\
\hline $\begin{array}{l}\text { 2. Страв од заразување } \\
\text { со вирусот преку } \\
\text { директен контакт со } \\
\text { здравствениот систем }\end{array}$ & $0,14^{*}$ & - & & & & & & \\
\hline $\begin{array}{l}\text { 3. Согледан здравствен } \\
\text { статус }\end{array}$ & $0,18^{*}$ & $0,33^{* *}$ & - & & & & & \\
\hline $\begin{array}{l}\text { 4. Согледан ризик за } \\
\text { КОВИД-19 }\end{array}$ & $0,15^{*}$ & $0,50 * *$ & $0,43 * *$ & - & & & & \\
\hline $\begin{array}{l}\text { 5. Сознанија за } \\
\text { КОВИД-19 0,23** }\end{array}$ & $-0,10$ & 0,01 & $0,21 * *$ & - & & & & \\
\hline 6. Депресија & $0,24 * *$ & $0,39 * *$ & $0,28^{* *}$ & $0,28 * *$ & 0,05 & - & & \\
\hline 7. Оптимизам & $-0,07$ & $-0,20 * *$ & $-0,27 * *$ & $-0,20^{* *}$ & 0,01 & $-0,33^{* *}$ & - & \\
\hline 8. Социјална поддршка & 0,01 & $-0,09$ & $-0,34 * *$ & $-0,22$ & 0,11 & $-0,15^{*}$ & $0,24 * *$ & \\
\hline Просек & 3,07 & 3,16 & 3,27 & 2,86 & 4,08 & 1,70 & 3,65 & - \\
\hline СД & 1,17 & 1,20 & 0,93 & 0,90 & 0,76 & 0,58 & 0,66 & \\
\hline Можен опсег & $1-5$ & $1-5$ & $1-5$ & $1-5$ & $1-5$ & $1-4$ & $1-5$ & \\
\hline Реален опсег & $1-5$ & $1-5$ & $1-5$ & $1-5$ & $1-5$ & $1-3,90$ & $1,29-5$ & \\
\hline
\end{tabular}

$\left({ }^{*} p<0,05 ; \quad * * p<0,01 ; \quad\right.$ СД $=$ Стандардна девијација $)$

лекар за време на КОВИД-19 изнесува 3,07 (СД $=1,17$, опсег 1-5), што значи дека контактот со матичен лекар е релативно висок за време на епидемијата со КОВИД-19. Покрај тоа, просечната вредност на социјалната поддршка е релативно висока.

Контакт со матичен лекар: Извршен е пример тест за да се оценат промените во контактот со матичниот 
лекар пред и за време на епидемијата на КОВИД-19. Откриено е статистички значително намалување на контактот со матичниот лекар пред појавата на КОВИД-19 (просек $=3,29$, СД $=1,11$ ) и за време на епидемијата со КОВИД-19 $($ просек $=3,07$, СД $=1,17), \mathrm{t}(157)=3,78$, $\mathrm{p}<0,001$ (пар 2).

\section{Асоцијации помеѓу променливи-} те на студијата: Како што може да се забележи од Табела 2, асоцијациите меѓу варијаблите на студијата покажуваат дека контактот со матичен лекар значително и позитивно се поврзува со согледаниот здравствен статус, согледаниот ризик за КОВИД-19, сознанијата за КОВИД-19 и депресијата. Со други зборови, колку повеќе учесници го сфатиле својот здравствен статус како умерено лош, сметале дека се изложе- здравствениот систем значително и позитивно се поврзува со согледаниот здравствен статус, согледаниот ризик за КОВИД-19 и депресијата; додека негативно се поврзува со оптимизмот. Имено, колку повеќе учесници го сфатиле својот здравствен статус како умерено лош, сметале дека се изложени на поголем ризик од заразување со КОВИД-19, имале поголема депресија и помал оптимизам; толку повеќе се плашеле од заразување со вирусот преку директен контакт со здравствениот систем. Покрај тоа, согледаниот здравствен статус значително и позитивно се поврзува со согледаниот ризик од КОВИД-19 и депресијата, а негативно се поврзува оптимизмот и социјалната поддршка. Пронајдени се позитивни значајни асоцијации кои го поврзуваат согледаниот

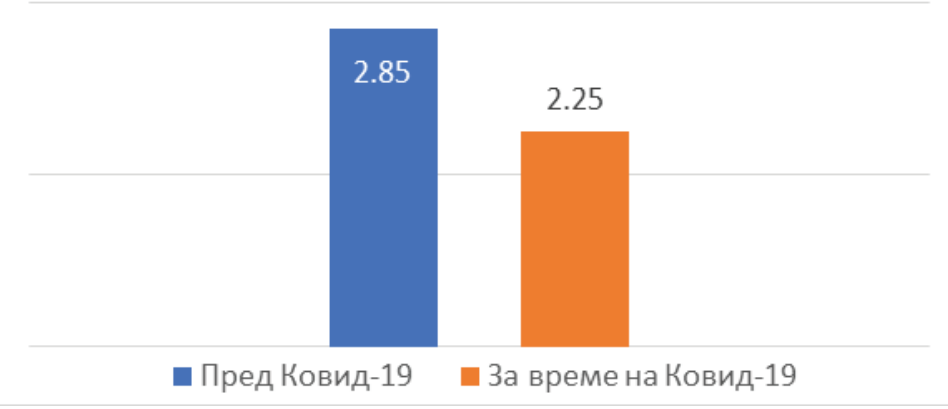

ни на поголем ризик да се заразат со КОВИД-19, имале повеќе сознанија за КОВИД-19 и имале поголеми нивоа на депресија; толку повеќе биле во контакт со својот матичен лекар за време на КОВИД-19. Стравот од заразување со вирусот преку директен контакт со ризик за КОВИД-19 со сознанијата за КОВИД-19 и депресијата. Со други зборови, колку повеќе учесници го сфатиле својот здравствен статус како умерено лош, сметале дека се изложени на поголем ризик да се заразат со КОВИД-19, имале поголеми сознанија 
за КОВИД-19 и повисоки нивоа на депресија; толку повеќе биле во контакт со својот матичен лекар за време на КОВИД-19. Стравот од заразување со вирусот преку директен контакт со здравствениот систем значително и позитивно се поврзува со согледаниот здравствен статус, согледаниот ризик за КОВИД-19 и депресијата; додека негативно се поврзува со оптимизмот. Имено, колку повеќе учесници го сфатиле нивниот здравствен статус како умерено лош, сметале дека се изложени на поголем ризик од заразување со КОВИД-19, имале поголема депресија и помал оптимизам; толку повеќе се плашеле од заразување со вирусот преку директен контакт со здравствениот систем. Покрај тоа, согледаниот здравствен статус значително и позитивно се поврзува со согледаниот ризик за КОВИД-19 и депресијата, додека негативно се поврзува со оптимизмот и социјалната поддршка. Утврдени се позитивни значајни асоцијации кои го поврзуваат согледаниот ризик за КОВИД-19 со сознанијата за КОВИД-19 и депресијата. Утврдени се негативни значајни асоцијации помеѓу согледаниот ризик од КОВИД-19 и оптимизмот. Утврдени се негативни значајни асоцијации кои ги поврзуваат депресијата, оптимизмот и социјалната поддршка; утврдена е позитивна значајна асоцијација помеѓу оптимизмот и социјалната поддршка.

Ретрресивна анализа за ияенйификување на корелацијайа на кон-

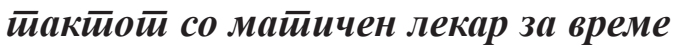

на КОВИД-19: Наодите покажаа дека целосниот модел на регресија е значаен $(F(6,143)=2,70, p<0,05)$ и објаснува $6 \%$ од варијансата во контактот со матичен лекар за време на КОВИД-19. Како што може да се забележи во Табела 3, се чини дека поголем степен на контакт со матичен лекар за време на КОВИД-19 е поврзан со помало ниво на сознанија за КОВИД-19.

Рет̄ресивна анализа за ияенйификување на корелацијайа на сйравой оg заразување со вирусой иреку gирекйен конйакй со здравсиивениой сисиием: Наодите укажуваат дека моделот на целосна регресија е значаен $(F(8,136)=14,11, p<0,001)$ и објаснуваат $42 \%$ од варијансата во стравот од заразување со вирусот преку директен контакт со здравствениот систем. Како што може да се забележи во Табела 4, се чини дека поголем степен на страв од заразување со вирусот преку директен контакт со здравствениот систем за време на КОВИД-19 се поврзува со понискиот степен на образование, повисокиот согледан ризик за КОВИД-19 и помалите сознанија за КОВИД-19.

\section{Дискусија}

Со оваа студија се врши обид да се охрабрат повозрасните лица кои имаат потреба од третман и нега да ги користат здравствените услуги за време на епидемијата со КОВИД-19. Оттука, целта на студијата беше да се испитаат детерминантите на здравствените ис- 
Табела 3. Регресивна анализа за контакт со матичен лекар за време на КОВИД-19 (n= 261)

Зависна променлива

Независни променливи

Согледана здравствена состојба

Согледан ризик за КОВИД-19

Сознанија за КОВИД-19

Депресија

Оптимизам

Социјална поддршка

Прилагоден $\mathrm{R}^{2}$

$\mathrm{F}(\mathrm{df})$ Контакт со матичен лекар за време на КОВИД-19

$(* * p<.05)$

куства на повозрасните лица за време на КОВИД-19.

Наодите од студијата покажаа дека контактот на повозрасните лица со матичен лекар бил намален за време на пандемијата со КОВИД-19, во споредба со пред појавата на вирусот. Ова намалување на контактите со матичниот лекар кај повозрасните лица за време на КОВИД-19 е загрижувачко од три главни причини: Прво, се покажа дека намаленото користење на здравстве-

Табела 4. Регресивна анализа на страв од заразување со КОВИД-19 преку директен контакт со здравствениот систем $(n=261)$

Зависна варијабла

Независни променливи

Пол

Години на образование

Согледана здравствена состојба

Согледан ризик за КОВИД-19

Сознанија за КОВИД-19

Депресија

Оптимизам

Социјална поддршка
Страв од заразување со КОВИД-19 преку директен контакт со здравствениот систем

\begin{tabular}{lc}
\hline Прилагоден $\mathrm{R}^{2}$ & $0,42 * * *$ \\
\hline $\mathrm{F}(\mathrm{df})$ & $14,11(8.136)$ \\
\hline
\end{tabular}

$(* p<0,05, \quad * * * p \quad<0,001)$ 
ните капацитети (на пример, помалку контакт со матичен лекар) е поврзано со пониски здравствени индикатори (Wang et al., 2012). Второ, матичните лекари играат значајна улога во борбата на повозрасните лица да се справат со проблемите со здравјето, бидејќи постарите луѓе најчесто првично се обраќаат до својот матичен лекар којшто треба да се справи со нивните медицински и ментални поплаки (Elliott et al., 2018). Одржувањето контакт со матичниот лекар е особено важно за време на пандемија, со оглед на тоа што многу повозрасни лица доживуваат пад на физичките и менталните индикатори како резултат на социјалното дистанциpaње (Tyrrell and Williams, 2020). Трето, имајќи предвид дека повозрасни лица се изложени на поголем ризик од тешко заболување и морталитет (Shahid et al., 2020), општиот дискурс за КОВИД-19 глобално ги прикажува како ранлива група. Соодветно на тоа, „наративот за товар“ на постарата популација цвета поради пренатрупаниот здравствен систем кој не може да обезбеди соодветна грижа за сите (Ayalon, 2020). Можно е повозрасните лица да го намалиле контактот со здравствениот систем како резултат на овој „наратив за товар“.

Во сегашната студија, повисок степен на контакт со матичниот лекар се поврзува со поголеми сознанија за КОВИД-19. Овој наод е во согласност со претходната студија спроведена за време на епидемијата со Тешкиот акутен респираторен синдром (САРС) во 2003 година, која откри дека поради ограниченото знаење за САРС, луѓето се плашеа да бараат здравствени услуги (Lu, Chou and Liou, 2007). Наодот дека сознанијата за КОВИД-19 се важна одредница за контактот со матичниот лекар за време на КОВИД-19 е значајно за сите коишто шират информации за јавното здравје за време на здравствени кризи. Соодветно на тоа, здравствените лидери треба да ја идентификуваат ранливата популација којашто можеби не е доволно писмена или не е поврзана на социјалните мрежи на Интернет и како резултат на тоа, да пренесуваат пораки преку други, поефикасни средства, кои имаат поголема можност да допрат до ваквата популација.

Во оваа студија, стравот од заразување со вирусот преку директен контакт со здравствениот систем за време на епидемијата со КОВИД-19 беше релативно висок. Ваквиот наод не е изненадувачки, имајќи предвид дека за време на периодот кога беше спроведена тековната студија, здравствените власти и медиумите ги прикажуваа повозрасните лица како ранлива популација, со висок ризик од заразување со КОВИД-19 (Ayalon, 2020). Повозрасните лица добија насоки да ги почитуваат мерките за изолација и да го ограничат своето движење (М3, 2020 година). Покрај тоа, се тврдеше дека за време на КОВИД-19, израелското МЗ усвои стратегија заснована на страв (Basis et al., 2020). Иако создавањето страв од здравствена закана може да вроди со плод кај луѓето и со тоа да се намалат шансите за заразување со оваа болест, 
екстремното ниво на страв може да направи повеќе штета отколку корист. Се претпоставува дека стратегијата на израелското Министерство за здравство може да влијаела на неповолен начин врз граѓаните - поттикнувајќи ги да ги гледаат здравствените услуги како места на зараза (Basis et al., 2020).

Нашите наоди укажуваат дека повисок степен на страв од заразување со вирусот преку директен контакт со здравствениот систем за време на КОВИД-19 се поврзува со повисок ризик за КОВИД-19, пониско ниво на образование и помали сознанија за КОВИД-19. Овие наоди укажуваат на важноста од обезбедување точни информации и пораки до повозрасните лица, кои може да не се лесно достапни во однос на посовремените (базирани на технологии) методи, заради нивото на образование и околностите на социјалната изолација (So et al., 2004). Ваквите пораки треба да го пренесат значењето на одржување рутински контакт со здравствениот систем за време на пандемиска криза.

Оваа студија има важни импликации. Според резултатите од студијата, клиничките интервенции насочени кон нивото на образование на повозрасните лица, согледаниот ризик за КОВИД-19 и сознанијата за КОВИД-19 може да ги охрабрат повозрасните лица да бараат здравствени услуги за време на глобална епидемија, доколку е потребно. Здравствените работници можат да ги користат тековните наоди за да имаат поцелосна слика за профилите на повозрасните лица кои избираат да го намалат контактот со својот матичен лекар за време на пандемијата. Исто така, во време на пандемија, се препорачува медицинскиот персонал да иницира проактивни телефонски повици кон повозрасните лица и интерес за нивната физичка и ментална благосостојба. Ваквите разговори отвораат можност да се дадат објаснувања за тоа како здравствените служби се подготвени да ги третираат повозрасни лица за време на епидемија. Паралелно со ова, здравствените услуги треба да обезбедат неопходна грижа и третман за повозрасните лица, истовремено намалувајќи ја можноста за заразување со вирусот.

Иако оваа прелиминарна студија е ограничена по својата репрезентативност и дизајнот на самостојниот извештај, што може да влијае на неговата генерализација; и покрај фактот дека медицинската историја на учесниците не беше проценувана и сите учесници беа дел од истата ОЗН, оваа студија дава пионерски увид во потенцијалните негативни здравствени импликации поврзани со пандемијата со КОВИД-19 кај повозрасните лица. Понатаму, оваа студија ги нагласува квалитетите и факторите што ги охрабруваат/ обесхрабруваат повозрасни лица да користат здравствени услуги за време на епидемија со вирус, како што е пандемијата КОВИД-19.

Сe предлага да се спроведат понатамошни лонгитудинални студии, кои ќе ги испитаат медицинските ин- 
дикатори и другите психосоцијални фактори кои може да се поврзани со искуствата на оваа популација во однос на здравствените услуги кај поголем дел од повозрасната популација и во подолги временски периоди. Ваквите студии ќе овозможат создавање прилагодени програми за интервенција при евентуално повторување на друга здравствена пандемија.
Изјави:

Финансирање - Авторите не добија никакви средства за спроведување на оваа студија.

Конкурентни интереси - Авторите изјавуваат дека не постои никаков конкурентен интерес во однос на овој труд.

\section{Користена литература}

Adar, T., Levkovich, I., Castel, O. C. and Karkabi, K. (2017), 'Patient's utilization of primary care: a profile of clinical and administrative reasons for visits in Israel', Journal of Primary Care and Community Health, 8,4, 221-227.

Ayalon, L. (2020), 'There is nothing new under the sun: Ageism and intergenerational tension in the age of the COVID-19 outbreak', International Psychogeriatrics, 1-4.

Bentur, N. and Heymann, A. D. (2020), 'Depressive symptoms and use of health services among older adults in Israel', Israel Journal of Health Policy Research, 9, 1-6.

Basis, F., Zeidani, H., Hussein, K. and Hareli, S. (2020), 'Drastic reduction in patient visits to the emergency department in a hospital in Israel during the COVID-19 outbreak, compared to the H1N1 2009', International Journal of Health Policy and Management.'

Castro-Costa, E., Dewey, M., Stewart, R., Banerjee, S., Huppert, F., Mendonca-Lima, C. ... and Tsolaki, M. (2007), 'Prevalence of depressive symptoms and syndromes in later life in ten European countries: the SHARE study', The British Journal of Psychiatry, 191.5, 393-401.

DeViva, J. C., Sheerin, C. M., Southwick, S. M., Roy, A. M., Pietrzak, R. H. and HarpazRotem, I. (2016), 'Correlates of VA mental health treatment utilization among OEF/ OIF/OND veterans: Resilience, stigma, social support, personality, and beliefs about treatment', Psychological Trauma: Theory, Research, Practice and Policy, 8,3, 310 .

Elliott, J., Stolee, P., Boscart, V., Giangregorio, L. and Heckman, G. (2018), 'Coordinating care for older adults in primary care settings: understanding the current context', $B M C$ Family Practice, 19,1, 137.

Garcia, S., Albaghdadi, M. S., Meraj, P. M., Schmidt, C., Garberich, R., Jaffer, F. A. ... and Huang, P. P. (2020), 'Reduction in ST-segment elevation cardiac catheterization laboratory activations in the United States during COVID-19 pandemic', Journal of the American College of Cardiology, 75,22, 2871-2872. 
Irwin, M., Artin, K.H. and Oxman, M.N. (1999), 'Screening for depression in the older adult: Criterion validity of the 10-item centre for epidemiological studies depression scale (CES-D)', Archives of Internal Medicine, 159, 1701-1704.

Jahromi, V. K., Mehrolhassani, M. H., Dehnavieh, R. and Anari, H. S. (2017), 'Continuity of care evaluation: The view of patients and professionals about urban family physician program', International Journal of Preventive Medicine, 8.

Kohout, F.J., Berkman, L.F., Evans, D.A., et al. (1993), 'Two shorter forms of the CES-D (Centre for Epidemiological Studies-Depression) depression symptoms index', Journal of Aging and Health, 5, 179-193.

Lazzerini, M., Barbi, E., Apicella, A., Marchetti, F., Cardinale, F. and Trobia, G. (2020), 'Delayed access or provision of care in Italy resulting from fear of COVID-19', The Lancet Child and Adolescent Health, 4,5, e10-e11.

Li, D., Zhang, D. J., Shao, J. J., Qi, X. D. and Tian, L. (2014), 'A meta-analysis of the prevalence of depressive symptoms in Chinese older adults', Archives of Gerontology and Geriatrics, 58, 1, 1-9.?

Morrow-Howell, N., Galucia, N. and Swinford, E. (2020), 'Recovering from the COVID-19 pandemic: A focus on older adults', Journal of Aging and Social Policy, 1-9.?

Radloff, L.S. (1977), 'The CES-D scale: A self-report depression scale for research in the general population', Applied Psychological Measurement, 1, 358-401.

Radwan, E., Radwan, A. and Radwan, W. (2020), 'Challenges Facing Older Adults during the COVID-19 Outbreak', European Journal of Environment and Public Health, 5,1, em0059?

Rastogi, D., Madhok, N. and Kipperman, S. (2013), 'Caregiver asthma knowledge, aptitude, and practice in high healthcare utilizing children: effect of an educational intervention', Pediatric Allergy, Immunology and Pulmonology, 26,3, 128-139.

Santini, Z. I., Jose, P. E., Cornwell, E. Y., Koyanagi, A., Nielsen, L., Hinrichsen, C. ... and Koushede, V. (2020), 'Social disconnectedness, perceived isolation, and symptoms of depression and anxiety among older Americans (NSHAP): a longitudinal mediation analysis', The Lancet Public Health, 5,1, e62-e70.

Scheier, M.F., Carver, C.S. and Bridges, M.W. (1994), 'Distinguishing optimism from neuroticism (and trait anxiety, self-mastery, and self-esteem): A re-evaluation of the life orientation test', Journal of Personality and Social Psychology, 67, 1063-1078.

Shahid, Z., Kalayanamitra, R., McClafferty, B., Kepko, D., Ramgobin, D., Patel, R. ... and Jones, K. (2020), 'COVID-19 and older adults: what we know', Journal of the American Geriatrics Society, 68,5, 926-929.

Shinan-Altman, S. and Levkovich, I. (2020), 'COVID-19 precautionary behaviour: The Israeli case in the initial stage of the outbreak'.

Shinan-Altman, S., Levkovich, I. and Tavori, G. (2020), 'Healthcare utilization among breast cancer patients during the COVID-19 outbreak', Palliative and Supportive Care, 1-7.

So, W. K., Chan, S. S., Lee, A. C. and Tiwari, A. F. (2004), 'The knowledge level and precautionary measures taken by older adults during the SARS outbreak in Hong Kong', International Journal of Nursing Studies, 41,8, 901-909. 
Tyrrell, C. J. and Williams, K. N. (2020), 'The paradox of social distancing: Implications for older adults in the context of COVID-19', Psychological Trauma: Theory, Research, Practice and Policy, 12,S1, S214.

Wang, S. Y., Chen, L. K., Hsu, S. H. and Wang, S. C. (2012), 'Health care utilization and health outcomes: a population study of Taiwan', Health Policy and Planning, 27,7, 590-599.

Wang, J., Kong, D., Sun, B. C. and Dong, X. (2020). Health services utilization among Chinese American older adults: Moderation of social support with functional limitation. Journal of Applied Gerontology, 39(5), 481-489.'

World Health Organization (WHO). COVID-19: Operational guidance for maintaining essential health services during an outbreak. World Health Organization. (2020). Retrieved from https://www.who.int/publications-detail/covid-19-operational-guidancefor-maintaining-essential-health-services-during-an-outbreak.

Zhang, J.M., Zhang, D. and Chock, T.M. (2014). Effects of HIV/AIDS public service announcements on attitude and behaviour: Interplay of perceived threat and self-efficacy. Social Behaviour and Personality: An International Journal, 42(5), 799-809. 